\title{
Relations EQ (Emotional Quotient) with Learning Result Bung Hatta University Biology Education Student
}

\section{Wince Hendri and Dwi Permatasari}

Biology Education, Faculty educational and Pedagogy Bung Hatta University

\section{Abstract}

Emotional Quotient is one of the factors that influence the success of student results. This study aimed to describe the level of EQ student Bung Hatta University Biology Education and Analyzing the relationship between the level of learning result masiswa EQ with Bung Hatta University Biology Education. This research is quantitative descriptive correlational approach. The population in this study were 43 students consisting of forces in 2013, 2014, and 2015. The samples included a total of 39 students. Based on data normality test in SPSS 22.0 using the Kolmogorov-Smirnov statistic, obtained results with the results of the distribution of normality EQ Asym. 2 Sig.

Received: 18 January 2019 Accepted: 24 March 2019 Published: 31 March 2019

Publishing services provided by Knowledge E

(c) Wince Hendri and Dwi Permatasari. This article is distributed under the terms of the Creative Commons

Attribution License, which permits unrestricted use and redistribution provided that the original author and source are credited.

Selection and Peer-review under the responsibility of the First ELEHIC Conference Committee. (2-tailed).403 and distribution normality learning achievements with the result Asym. 2 Sig. (2-tailed) 0.402 , normally distributed because it exceeds the significance level of $>$ 0.05 . Linearity test results obtained linear regression equation is $Y=2.958+0,006 \mathrm{X}$, while for the $F$ value obtained test results the relationship between independent variables and the dependent variable is the significance 0.119>0.05 and Fhitung $<$ Ftabel amount of $(1.791<4.11)$, which means that there is a linear relationship between independent variables with the dependent variable. Furthermore, the significance of the correlation coefficient is smaller than the value rtabel $(0.267<0.316)$ or the significance value of 0.100 , which means greater than $0.05(0.100>0.05)$. These results, obtained that the relationship between these two variables were not significant.

Keywords: emotional quotient, results learning, biology education

\section{Introduction}

Learning is a process that takes place actively and integrated by using various forms of action to achieve a goal [1]. One of the goals of learning is learning achievement that includes cognitive domains (includes facts and knowledge), affective (including attitudes), psychomotor (include acting skills). The third domain, cognitive domain is the 
domain of the most dominating and prominent as it relates to students' ability to master the subject matter, and is often used as a benchmark of student success [2].

In the learning process will be a lot of problems that arise that can not be solved simply by using intellectual abilities. Emotional maturity turned out to be critical to its success. In other words, emotional intelligence has a huge contribution in achieving success in life [3].

Someone who has a high emotional intelligence is a person who is able to control myself, patience, perseverance, not emotionally, not reactive, and positive thinking [4]. Student learning outcomes are influenced by two main factors, namely internal factors and external factors [5].

One that affect student learning outcomes is intelligence. Intelligence affects the learning progress, the fact that students with high intelligence level is not necessarily succeed in learning. This is because intelligence is only one factor among many factors that affect learning outcomes, according to Goleman [6].

Intelligence is the basic factors that predict academic performance in school and an important role in influencing the success of students in the future [7]. Intellectual or Intelligence Quotient (IQ) only contributed 20 percent to the success, while 80 percent is a contribution factor other forces, such as emotional intelligence or Emotional Quotient (EQ).

Emotional intelligence influence and play an important role in improving learning outcomes [8].To view student learning outcomes achieved during a certain period of time in some it will be held for an evaluation study. Results of the assessment of the results of student learning lecturer with the goal that has been set is referred to as academic achievement. Various judgments in the process of learning provided through assignments, midterms (UTS) and final exams (UAS) of the lecture material given. The results of the students' learning process called performance index. GPA is the final formulation given by professors on student results. Intellectual acumen is often measured by the value of performance index, an index value of a good performance or frequent champion is a measure of one's success. Benchmarks have not one, but not one hundred percent justified. There are other factors that cause a person to become successful is their emotional intelligence. Student learning outcomes determined more by internal factors of 70 percent, while external factors affected only 30 percent [2].

According to Uno [9], Emotional intelligence is the ability to motivate yourself and endure frustration, impulse control and not exaggerating pleasure, set the mood and keep the load stress does not overwhelm the capacity to think, empathize and pray. According to Hill and Istarani, [10] of emotional intelligence or Emotional Quotient (EQ) 
is the knowledge to know yourself, self-awareness, social awareness, empathy, and the ability to communicate well with others.

Based on the above research titled "The Relationship of Emotional Intelligence (Emotional Quotient) With Learning Outcomes Masiswa Bung Hatta University Biology Education Force Year 2016/2017". This study aimed to describe the level of EQ masiswa Bung Hatta University Biology Education and Analyzing the relationship between the level of learning outcomes masiswa EQ with Bung Hatta University Biology Education.

\section{Methods}

The study was conducted in Biology Education Program S1 University of Bung Hatta. This research is quantitative descriptive correlational approach. The population in this study were 43 students consisting of forces in 2013 , class of 2014 , class of 2015 . The samples included a total of 39 students.

The data collection technique using emotional intelligence questionnaire students based on indicators of the theory proposed by Salovey [6]. There are five indicators in this study, namely recognizing emotions, managing emotions, motivating oneself, recognizing emotions in others, and build relationships. While learning achievementviewed from the final GPA of each student.

Analysis of data using simple regression analysis between EQ and academic achievement of students of Biology Education, to determine the relationship between EQ with the achievement of students of Biology Education using SPSS for windows. Test requirements analysis is to determine the data normality test each variable normal distribution or not, then the linearity test to determine the relationship between independent variables and the dependent variable is linear [11].

\section{Result}

\subsection{Emotional intelligence data description}

Emotional intelligence variable data obtained through a questionnaire consisting of five indicators with 30 items of the statement and the number of respondents as many as 39 students. Emotional intelligence questionnaire used student using a Likert scale with four alternative answers. The results of the data analysis emotional intelligence scores of students are presented in the following table. 
TABLE 1: Average Score EQ students.

\begin{tabular}{l|c|c|}
\hline variables & Average & Criteria \\
\hline Emotional intelligence & $90.44 \pm 9.679$ & High enough \\
\hline Source: Data were analyzed using SPSS 22.0 &
\end{tabular}

Based on the analysis of data in table 1 is known that the average score of students $E Q$ obtained at 90.44. This shows that the students have a fairly high level of EQ. In more detailed overview of the EQ of students in terms of each indicator as follows:

TABLE 2: Average Score EQ Students Based Indicators.

\begin{tabular}{l|l|c|c|}
\hline No. & Indicator & Average & Criteria \\
\hline 1 & Recognizing Emotions Self & $17.23 \pm 2.367$ & High enough \\
\hline 2 & Managing Emotions & $16.51 \pm 2.543$ & High enough \\
\hline 3 & Motivating Yourself & $18.82 \pm 2.522$ & High enough \\
\hline 4 & Recognizing Emotions Others & $19.54 \pm 2.415$ & High enough \\
\hline 5 & fostering Relationships & $18.33 \pm 2.994$ & High enough \\
\hline Source: Data were analyzed using SPSS 22.0 & \\
\end{tabular}

Based on the analysis of data in Table 2 that the average score of students EQ indicator, which recognize the emotions of $17.23,16.51$ managing emotions, motivating oneself 18.82, 19.54 recognize other people's emotions, and relationships 18.33. These results indicate that the EQ level students based on each of the indicators included in the criteria is quite high and the highest indicator scores acquisition is recognizing the emotions of others.

\subsection{Learning achievement data description}

Learning achievement variable data obtained from studies documentation to see the final GPA of students by the number of respondents 34 students. Belajarmahasiswa achievement data analysis are presented in Table 3 below.

TABLE 3: Average Value of Learning Achievement Students.

\begin{tabular}{|c|c|c|}
\hline variables & Average & Criteria \\
\hline GPA & $3.49 \pm 0.2153$ & Good \\
\hline
\end{tabular}


Based on the analysis of data in Table 3 is known that the average value of the biology student learning outcomes obtained at 3.49. This shows that the achievement of students that are in both criteria.

\subsection{Analysis}

Prior to testing hypotheses, test requirements analysis is to determine the data normality test each variable normal distribution or not, then the linearity test to determine the relationship between independent variables and dependent variable is linear. Prerequisite testing data analysis was performed using SPSS 22.0 with the specified test criteria.

Based on the test normalitas the data in SPSS 22.0 using the Kolmogorov-Smirnov statistic, normality of the distribution of the results obtained with the results Asym emotional intelligence. 2 Sig. (2-tailed).403 and distribution normality learning achievements with the result Asym. 2 Sig. (2-tailed) 0.402 . This means that the respective data are normally distributed variable because it exceeds the significance level of $>0.05$.

Based on the test results obtained linearity of the linear regression equation is $Y=$ $2.958+0,006 \mathrm{X}$, which means that each additional units of independent variables will result in increasing the dependent variable of 0.006 . As for the value of $F$ obtained test results the relationship between independent variables and the dependent variable is the significance $0.119>0.05$ and Fhitung $<$ Ftabel amount of $(1.791<4.11)$, which means that there is a linear relationship between independent variables with the dependent variable. Based on the test results of linearity, meaning linear assumptions are met and to proceed with the research hypothesis testing.

The hypothesis of this study is the null hypothesis $\left(\mathrm{H}_{0}\right)$ That there is no relationship between the level of emotional intelligence and academic achievement of students, and the alternative hypothesis $(\mathrm{H} 1)$ that there is a relationship between the level of emotional intelligence and academic achievement of students. To answer these hypotheses can be obtained by analyzing the data in Table 4 below:

TABLE 4: Pearson Correlation Test Results.

\begin{tabular}{|c|c|c|c|}
\hline variables & rhitung (r xy) & rtabel & significance \\
\hline $\begin{array}{l}\text { Emotional intelligence } \\
\text { and academic } \\
\text { achievement }\end{array}$ & 0.267 & 0,316 & 0,100 \\
\hline
\end{tabular}

Based on Table 4, it can be seen that the interpretation of the correlation coefficient is at a low level of relationship. Furthermore, the significance of the correlation coefficient 
is smaller than the value rtabel $(0.267<0.316)$ or the significance value of 0.100 , which means greater than $0.05(0.100>0.05)$. These results, obtained that the relationship between these two variables were not significant. Then $\mathrm{HO}$ accepted, which means there is no relationship between the level of emotional intelligence and academic achievement of students of Biology Education Studies Program Bung Hatta University.

\section{Discussion}

Based on the calculations and data analysis can be seen that there is no relationship between the level of emotional intelligence and academic achievement of students of Biology Education Studies Program University of Bung Hatta, thus the conclusions expressed in this study are not in accordance with what is stated by Richard Hermstein and Charles Murray in his book The Bell Curve, Which put the weight of importance to the IQ, according them the highest IQ accounted for approximately 20 percent of the factors that determine success in life, so that 80 percent filled by other forces (Goleman, 2015: 42). Then based on that statement Goleman suggests that emotional intelligence which is included in the keeuatan outside forces.

This means that the high and low levels of emotional intelligence which is owned by the students, do not affect the achievement of students. Relationships in this study is not the direction that shows that emotional intelligence and learning achievement has the opposite tendency, namely the level of emotional intelligence of students are at a fairly high criteria, currently learning achievements are in good criterion. The results also supported by Maria Regina Wulandari (2016), that there is no relationship between EQ Achievement student results.

\section{Conclusion}

Based on the analysis and discussion of the drawn conclusion that emotional intelligence (Emotional Quotient) does not influence sefnifikan with Masiswa Education Learning Outcomes Biology, University of Bung Hatta Force Year 2016/2017, this conclusion is based on the calculation of correlation coefficients obtained rhitung smaller than the value rtabel $(0.267<0.316)$ or the significance value of 0.100 , which means greater than $0.05(0.100>0.05)$, then $\mathrm{HO}$ is accepted. 


\section{References}

[1] Soemanto, W. 2006. Educational Psychology. Jakarta: Rineka Reserved. 256 Page.

[2] Sudjana, N. 2010. Teaching and Learning Outcomes Assessment. Bandung: Youth Rosdakarya. 168 Page.

[3] Mustaqim. 2008. Educational Psychology. Yogyakarta: Student Library

[4] Hawari D. 2009. IQ, EQ, SQ Criteria CQ \& Human Resources (Leader) Qualified. Publishers Hall FKUI. Jakarta

[5] Slameto. 2010. Learning and Factors Affecting. Jakarta: Rineka Reserved. 194 Page.

[6] Goleman. 2015. Emotional Intelligence. Jakarta: PT. Gramedia Pustaka Utama. 483 Page.

[7] Kuncel, NR, Hezlett, SA, \& Ones, DS 2004. Academic performance, career potential, creativity, and job performance: Can one predict construct them all the Journal of Personality and Social Psychology, 86, 148-161.

[8] Ogundokun, MO and Adeyemo, DA 2010. Emotional Intelligence And Academic Achievement: The Moderating Influence Of Age, And extrinsic Intrinsic Motivation. The African Symposium (ISSN TX 6-342-323): An online journal of the African Education Research Network, 10 (2): 127-140

[9] Uno, HB 2008. New Orientation in Psychology of Learning. Jakarta: Earth Literacy. 231 Page.

[10] Hill, S and Istarani. 2015. Intelligence and Learning Styles. Terrain: Larispa Indonesia. 176 Page.

[11] Sugiyono. 2009. Quantitative and Qualitative Research Methods. Bandung: Alphabet. 332 Page. 